\title{
GROWTH AND PRODUCTIVITY OF ROSELLE (HIBISCUS SABDARIFFA L.) AS AFFECTED BY YEAST AND HUMIC ACID
}

\author{
Rasha S. El-Serafy \\ Horticulture Department, Faculty of Agriculture, Tanta University, Egypt.
}

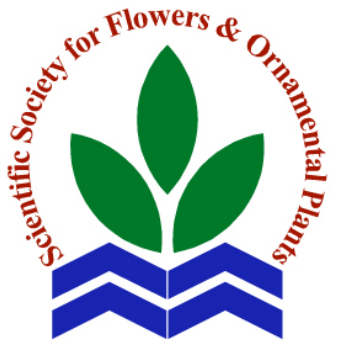

Scientific J. Flowers \& Ornamental Plants, 5(2):195-203 (2018).

Received: 24/2/2018

Accepted: 8/3/2018

ABSTRACT: This field study was undertaken at the Experimental Farm of Agriculture Faculty, Tanta University, during two seasons of 2015 and 2016 to investigate the efficiency of yeast and humic acid foliar application with the half recommended dose of NPK on plant growth, yield components and biochemical composition of roselle plant. The experiment consisted of five levels of yeast extract 0, 2, 4, 6 and $8 \mathrm{~g} / \mathrm{l}$ and three levels of humic acid i.e. 0, 1 and $2 \mathrm{~g} / \mathrm{l}$. Fifteen treatment combinations were laid out in a split plot design. Treatments were twice applied, the first application was 30 days after sowing while, the second one was 20 days after the first one. Yeast and humic acid combinations influenced positively on roselle productivity as it raised plant height, stem diameter, branch number, fruit number/plant, calices yield/plant compared to control plants. Total chlorophyll, carbohydrates and anthocyanin content were increased by yeast and humic acid applications. Total protein and macro elements $\mathrm{N}, \mathrm{P}$ and $\mathrm{K}$ showed an increase more so by the treatment of $8 \mathrm{~g} / \mathrm{l}$ yeast plus $2 \mathrm{~g} / \mathrm{l}$ humic acid.

So, it could be recommended for using foliar spray of yeast at concentration of $8 \mathrm{~g} / \mathrm{l}$ plus $2 \mathrm{~g} / \mathrm{l}$ humic acid with the half recommended dose of NPK for improving the growth and productivity of roselle plant.

Key words: Hibiscus sabdariffa L., roselle, biofertilizer, yeast, humic acid, anthocyanin, and macro elements.

\section{INTRODUCTION}

Recently, for modern horticultural production, the target goal of the researchers is organic farming with lower fertilizers input or developing new fertilizers or fertilization systems for increasing the nutrient uptake, growth and development of the plants, as well as improving the quality, quantity and environmental impact (Ahmed et al., 2011).

Bio-fertilizers are formulations of beneficial microorganisms which improve soil health, increase nutrients availability, also, are a renewable source of plant nutrients for substituting chemical fertilizers
(Boraste et al., 2009). Microbes formulation not only improve the availability of nitrogen and phosphorus for plants but also produce the healthy food (Oliver et al., 2013).

Saccharomyces cerevisiae (yeast) is used as a positive alternative to chemical fertilizers which is safety and environmentally (Omran, 2000). It is considered as a plant growth promoting for different crops during growth stages due to its high contents of auxins and cytokinins (Barnett et al., 1990) protein, amino acids and cryoprotective agent (Mahmoud, 2001). Yeast positively affected cell division, nucleic acid synthesis or chlorophyll formation and carbohydrates accumulation 
(Wanas, 2006). Root development may be enhanced by yeast application (Nassar et al., 2005; El-Tarabily and Sivasithamparam, 2006; Cloete et al., 2009). Some plants showed an improvement in their growth and productivity by yeast foliar spray application (Fathy et al., 2000; Abou-Aly, 2005 and Wanas, 2006).

Humic acid (HA) is the end product of chemical and biological transformations of organic matter. The functional groups of humic acid include carboxyl alcoholic hydroxyl, quinoid, phenolic hydroxyl and ketone in addition to protein, amino acids and several vitamins (Mahmoud, 2001). Humic acid increased cell membrane permeability, oxygen uptake, photosynthesis, respiration rate, nutrients uptake as well as root cell elongation and seed germination rate (Russo and Berlyn, 1990). Sprayed roselle with humic acid achieved an increase in plant growth and seed yield/ plant (Ahmed et al., 2011). Humic acid had promoting effect on the growth of Mentha piperita when used as a foliar spray (Hendawy et al., 2015).

The subtropical plant roselle (Hibiscus sabdariffa L.) belongs to family Malvaceae (Mohamed et al., 2007) widely grown in Africa, South East Asia, and tropical countries. It is cultivated for its calices, stem, leaves and seeds where it's all parts have industrial, medicinal and other applications (Rao, 1996). Sepals are the economic parts of roselle plants as have high nutritional value (protein, fats, carbohydrates, fibre, oxalic, citric and malic acid, vitamin $\mathrm{C}$, $\beta$-carotene, calcium and iron) Ismail et al., 2008. Roselle is used in a lot of ways; the calices are used for home consumption as well as used for medicinal uses where, their juice has antibacterial properties (Aziz et al., 2007), also have a great therapeutic action for curing heart, nerve diseases and high blood pressure (Sharaf, 1962). Roselle is used for industrial uses too as its red beverage using as natural food coloring agents in jams, tea pies and deserts. Therefore the objectives of this study were to shed more light for evaluating the physiological role of biofertilizer based on yeast and organic fertilizer based on humic acid foliar applications on the plant growth, yield components and biochemical composition of roselle plant.

\section{MATERIALS AND METHODS}

\section{Plant material and experimental site:}

Seeds of roselle (Sabhya 17, dark red) were obtained from the Medicinal and Aromatic Institute, Ministry of Agriculture, Egypt. Two field experiments were undertaken at the Experimental Farm, Faculty of Agriculture, Tanta University, Tanta, Egypt ( $\left.30^{\circ} 47^{\prime} \mathrm{N}: 31^{\circ} 0^{\prime} \mathrm{E}\right)$.

\section{Crop, treatments, and experimental design:}

Roselle seeds were sown on 10 and 17 of April in 2015 and 2016 respectively, on plots with unit area of $10.5 \mathrm{~m}^{2}$ contained five rows $3 \mathrm{~m}$ length $70 \mathrm{~cm}$ apart at a spacing of $50 \mathrm{~cm}$ apart (intra-row spacing). Seedlings after crop establishment were thinned to plant per hill.

The plants have been received half recommended dose of NPK and the cultural practices were done as recommended by the Egyptian Ministry of Agriculture. The experiment consisted of five levels of yeast extract (0, 2, 4, 6 and $8 \mathrm{~g} / \mathrm{l})$ and three levels of humic acid (0, 1 and $2 \mathrm{~g} / \mathrm{l})$, Fifteen treatment combinations were laid out in a split plot design and replicated three times. Soil samples were taken to analyzed for physicochemical properties and presented in Table (a). These treatments were tested on roselle plants as twice foliar spray, the first application was 30 days after sowing while, the second one was 30 days after the first one.

\section{Data recorded:}

Plant samples were taken at the harvest stage for measured the following parameters:

\section{Determination of growth attributes:}

Plant height $(\mathrm{cm})$, branch number /plant and stem diameter (mm). 
Table a. Physical and chemical properties of experimental soil.

\begin{tabular}{|c|c|c|c|c|c|c|c|c|c|c|c|}
\hline $\begin{array}{l}\text { Texture } \\
\text { class }\end{array}$ & $\begin{array}{c}\text { EC } \\
\text { (mmhos) }\end{array}$ & pH & $\begin{array}{c}\text { Field } \\
\text { capacity } \\
(\%)\end{array}$ & $\begin{array}{c}\text { Mg } \\
(\mathbf{m g} / \mathbf{l})\end{array}$ & $\begin{array}{l}\mathrm{Na} \\
(\mathrm{mg} / \mathrm{l})\end{array}$ & $\begin{array}{c}\text { Ca } \\
(\mathrm{mg} / \mathrm{l})\end{array}$ & $\underset{(\mathrm{mg} / \mathrm{l})}{\mathrm{Si}}$ & $\begin{array}{l}\mathrm{HCO}_{3} \\
(\mathrm{mg} / \mathrm{l})\end{array}$ & $\begin{array}{c}\mathrm{N} \\
(\mathrm{mg} / \mathrm{kg})\end{array}$ & $\begin{array}{c}\mathbf{P} \\
(\mathrm{mg} / \mathrm{kg})\end{array}$ & $\begin{array}{c}\mathrm{K} \\
(\mathrm{mg} / \mathrm{kg})\end{array}$ \\
\hline $\begin{array}{l}\text { Clay } \\
\text { loam }\end{array}$ & 2.86 & 7.78 & 36.81 & 4.64 & 13.76 & 8.24 & 12.24 & 5.18 & 32.4 & 9.2 & 170.6 \\
\hline
\end{tabular}

Determination of yield components:

Fruit number/plant, fruit dry weight/plant (g) and calices dry weight /plant (g).

\section{Biochemical analysis:}

\section{Total chlorophyll content:}

Leaves chlorophyll content was determined before harvesting by 3 weeks with chlorophyll meter (SPAD-502, Minolta Co., Japan) and represented by SPAD value.

\section{Total carbohydrate percentage:}

Total carbohydrates was determined according to Herbert et al. (1971).

\section{Total anthocyanins percentage:}

Powder of dried calices was used for determination according to $\mathrm{Du}$ and Francis (1973).

\section{Total protein content:}

Total protein content was calculated by multiplied $\mathrm{N}$ value by 6.25 according to Pirie (1955).

\section{The macro elements ( $N, P$ and $K)$ :}

Dried leaves were used for determination according to Chapman and Pratt (1961).

\section{Statistical analysis:}

The analysis of variance (ANOVA) was performed to compare means using least significant difference (LSD) test at 0.05 level of probability according to Waller and Duncan (1969). The error mean squares of split plot design were homogenous (Bartlett's test). Combined analysis was calculated for studied characters in both seasons.

\section{RESULTS AND DISCUSSION}

Efficiency of yeast and humic acid foliar spray on Hibiscus sabdariffa $L$. growth attributes:

Results presented in Table (1) show the effect of yeast, humic acid and their interaction on plant height $(\mathrm{cm})$, number of branches/plant and stem diameter of Hibiscus sabdariffa L.

Regarding to the effect of yeast foliar spray, results illustrated that plant height was significantly affected by yeast application. Using the highest rate of yeast increased plant height, number of branches/plant and stem diameter. On the other hand, using the low rate of yeast recorded the least values in this respect compared to control plants. Humic acid significantly increased the growth parameters especially with the high rate relative to untreated plants.

Treated plants by the high rate of yeast $(8 \mathrm{~g} / \mathrm{l})$ in combination with humic acid (2 $\mathrm{g} / \mathrm{l})$ gave the best values of plant growth parameters (Table 1) which might be attributed to the role of humic acid which can be used as growth regulate-hormone improves plant growth (Albayrak and Camas, 2005). Humic acid acts an in direct role for stimulating plant growth through its interactions with plant membrane transporters responsible for nutrients uptake and membrane associated signal transduction cascades which regulate growth and development (Canellas and Olivares, 2014). It has been reported that the promoting action of yeast is due to its role as a co-factor for 60 enzymes that remove amine groups from amino acids which are necessary for producing energy required in several 
Table 1. Means of varietal differences of roselle growth and yield parameters under yeast and humic acid application on the combined analysis of two seasons.

\begin{tabular}{|c|c|c|c|c|c|c|}
\hline Treatments & $\begin{array}{l}\text { Plant height } \\
\text { (cm) }\end{array}$ & $\begin{array}{c}\text { Branch } \\
\text { number } \\
\text { /plant }\end{array}$ & $\begin{array}{c}\text { Stem } \\
\text { diameter } \\
(\mathrm{mm})\end{array}$ & $\begin{array}{c}\text { Fruit } \\
\text { number/plant }\end{array}$ & $\begin{array}{c}\text { Fruit dry } \\
\text { weight/plant } \\
\text { (g) }\end{array}$ & $\begin{array}{c}\text { Calyx dry } \\
\text { weight/plant } \\
\text { (g) }\end{array}$ \\
\hline \multicolumn{7}{|l|}{ Yeast extract (Y) } \\
\hline$Y_{1}(0 \mathrm{~g} / \mathrm{l})$ & 100.28 & 8.22 & 9.16 & 36.72 & 21.76 & 13.04 \\
\hline$Y_{2}(2 \mathrm{~g} / \mathrm{l})$ & 119.17 & 11.00 & 9.67 & 42.89 & 25.44 & 16.66 \\
\hline$Y_{3}(4 \mathrm{~g} / \mathrm{l})$ & 126.50 & 11.61 & 9.60 & 44.44 & 26.64 & 18.75 \\
\hline $\mathrm{Y}_{4}(6 \mathrm{~g} / \mathrm{l})$ & 142.89 & 12.56 & 9.70 & 47.33 & 27.56 & 18.84 \\
\hline$Y_{5}(8 \mathrm{~g} / \mathrm{l})$ & 158.33 & 13.50 & 9.79 & 48.67 & 28.15 & 20.14 \\
\hline $\mathbf{L S D}_{0.05}$ & 2.30 & 0.42 & 0.08 & 0.62 & 0.34 & 0.48 \\
\hline \multicolumn{7}{|l|}{ Humic acid (H) } \\
\hline $\mathrm{H}_{1}(\mathbf{0} \mathrm{g} / \mathrm{l})$ & 120.30 & 10.27 & 9.49 & 42.17 & 25.10 & 16.04 \\
\hline$H_{2}(1 \mathrm{~g} / \mathrm{l})$ & 130.60 & 11.40 & 9.58 & 44.07 & 26.03 & 17.77 \\
\hline $\mathrm{H}_{3}(2 \mathrm{~g} / \mathrm{l})$ & 137.40 & 12.47 & 9.68 & 45.80 & 26.59 & 18.65 \\
\hline $\mathbf{L S D}_{0.05}$ & 1.85 & 0.43 & 0.06 & 0.39 & 0.26 & 0.31 \\
\hline \multicolumn{7}{|l|}{ Interaction $\mathbf{Y} \times \mathbf{H}$} \\
\hline $\mathbf{Y}_{1} \times \mathbf{H}_{1}$ & 90.83 & 6.00 & 9.05 & 34.50 & 20.41 & 11.74 \\
\hline $\mathbf{Y}_{1} \times \mathbf{H}_{2}$ & 102.17 & 8.50 & 9.14 & 36.83 & 21.77 & 12.93 \\
\hline $\mathbf{Y}_{1} \times \mathbf{H}_{3}$ & 107.83 & 10.17 & 9.29 & 38.83 & 23.10 & 14.44 \\
\hline $\mathbf{Y}_{2} \times \mathbf{H}_{1}$ & 110.50 & 9.33 & 9.61 & 41.00 & 24.36 & 14.79 \\
\hline $\mathbf{Y}_{2} \times \mathbf{H}_{2}$ & 121.17 & 11.00 & 9.66 & 42.67 & 25.66 & 17.37 \\
\hline $\mathbf{Y}_{2} \times \mathbf{H}_{3}$ & 125.83 & 12.67 & 9.73 & 45.00 & 26.32 & 17.81 \\
\hline $\mathbf{Y}_{3} \times \mathbf{H}_{1}$ & 119.67 & 11.00 & 9.47 & 42.50 & 26.17 & 16.89 \\
\hline $\mathbf{Y}_{3} \times \mathbf{H}_{2}$ & 125.83 & 11.50 & 9.61 & 44.67 & 26.73 & 19.25 \\
\hline $\mathbf{Y}_{3} \times \mathbf{H}_{3}$ & 134.00 & 12.33 & 9.74 & 46.17 & 27.01 & 20.11 \\
\hline $\mathbf{Y}_{4} \times \mathbf{H}_{1}$ & 129.33 & 11.83 & 9.59 & 45.67 & 27.02 & 17.77 \\
\hline $\mathbf{Y}_{4} \times \mathbf{H}_{2}$ & 145.00 & 12.67 & 9.72 & 47.33 & 27.81 & 18.86 \\
\hline $\mathbf{Y}_{4} \times \mathbf{H}_{3}$ & 154.33 & 13.17 & 9.78 & 49.00 & 27.85 & 19.89 \\
\hline $\mathbf{Y}_{5} \times \mathbf{H}_{1}$ & 151.17 & 13.17 & 9.73 & 47.17 & 27.57 & 18.98 \\
\hline $\mathbf{Y}_{5} \times \mathbf{H}_{2}$ & 158.83 & 13.33 & 9.80 & 48.83 & 28.20 & 20.45 \\
\hline $\mathbf{Y}_{5} \times \mathbf{H}_{3}$ & 165.00 & 14.00 & 9.84 & 50.00 & 28.68 & 20.99 \\
\hline $\mathbf{L S D}_{0.05}$ & 4.15 & 0.97 & NS & NS & 0.600 & 0.69 \\
\hline
\end{tabular}

bioactivities including cell division, as well as its content of cytokines which affect cell divisions and enlargement as reported (Mahmoud, 2001; Mok and Mok, 2001 and El-Tarabily, 2004).

Efficiency of yeast and humic acid foliar spray on Hibiscus sabdariffa $L$. yield components:

As shown in Table (2) fruit number/plant was significantly increased by yeast application relative to untreated plants.
Using the high rate of yeast increased fruit number/plant, fruit dry weight/plant and calices dry weight/plant. Yeast increased plants content of growth regulators and vitamins which consequently reflected on the dry matter (Alonso et al., 2008; Hesham and Mohamed, 2011).

Yeast extract induced beneficial effects during all plant development stages and improved flower formation due to its high auxins and cytokinins content in addition, yeast raised carbohydrates accumulation, 
Table 2. Means of varietal differences of roselle growth and yield parameters under yeast and humic acid application on the combined analysis of two seasons.

\begin{tabular}{|c|c|c|c|c|c|c|c|}
\hline Treatments & Chlorophyll & $\begin{array}{c}\text { Carbohydrates } \\
(\%)\end{array}$ & $\begin{array}{c}\text { Anthocyanins } \\
(\%)\end{array}$ & $\begin{array}{l}\text { Protein } \\
(\%)\end{array}$ & $\begin{array}{c}\mathrm{N} \\
(\%)\end{array}$ & $\begin{array}{c}\mathbf{P} \\
(\%)\end{array}$ & $\begin{array}{l}\mathrm{K} \\
(\%)\end{array}$ \\
\hline \multicolumn{8}{|l|}{ Yeast extract (Y) } \\
\hline$Y_{1}(0 \mathrm{~g} / \mathrm{l})$ & 52.11 & 16.15 & 2.18 & 13.40 & 2.14 & 0.359 & 2.19 \\
\hline$Y_{2}(2 \mathrm{~g} / \mathrm{l})$ & 55.57 & 16.90 & 2.23 & 13.71 & 2.19 & 0.371 & 2.23 \\
\hline$Y_{3}(4 \mathrm{~g} / \mathrm{l})$ & 56.90 & 17.67 & 2.27 & 14.21 & 2.27 & 0.380 & 2.26 \\
\hline $\mathrm{Y}_{4}(6 \mathrm{~g} / \mathrm{l})$ & 58.02 & 18.13 & 2.31 & 14.70 & 2.35 & 0.395 & 2.29 \\
\hline$Y_{5}(8 \mathrm{~g} / \mathrm{l})$ & 58.92 & 18.63 & 2.34 & 15.80 & 2.53 & 0.425 & 2.32 \\
\hline $\mathrm{LSD}_{0.05}$ & 0.34 & 0.07 & 0.0002 & 0.14 & 0.02 & 0.0002 & 0.0002 \\
\hline \multicolumn{8}{|l|}{ Humic acid (H) } \\
\hline $\mathrm{H}_{1}(\mathbf{0} \mathrm{g} / \mathrm{l})$ & 54.45 & 17.05 & 2.24 & 13.68 & 2.19 & 0.373 & 2.23 \\
\hline$H_{2}(1 \mathrm{~g} / \mathrm{l})$ & 56.71 & 17.55 & 2.27 & 14.31 & 2.29 & 0.388 & 2.26 \\
\hline $\mathrm{H}_{3}(2 \mathrm{~g} / \mathrm{l})$ & 57.75 & 17.88 & 2.29 & 15.10 & 2.42 & 0.397 & 2.28 \\
\hline $\mathrm{LSD}_{0.05}$ & 0.23 & 0.03 & 0.0001 & 0.12 & 0.01 & 0.0001 & 0.0001 \\
\hline \multicolumn{8}{|l|}{ Interaction $\mathbf{Y} \times \mathbf{H}$} \\
\hline $\mathbf{Y}_{1} \times \mathbf{H}_{1}$ & 48.27 & 15.51 & 2.15 & 12.18 & 1.95 & 0.350 & 2.16 \\
\hline $\mathbf{Y}_{1} \times \mathbf{H}_{2}$ & 53.22 & 16.30 & 2.18 & 13.39 & 2.14 & 0.359 & 2.20 \\
\hline $\mathbf{Y}_{1} \times \mathbf{H}_{3}$ & 54.83 & 16.64 & 2.20 & 14.63 & 2.34 & 0.368 & 2.21 \\
\hline $\mathbf{Y}_{2} \times \mathbf{H}_{1}$ & 54.27 & 16.41 & 2.21 & 13.45 & 2.15 & 0.363 & 2.21 \\
\hline $\mathbf{Y}_{2} \times \mathbf{H}_{2}$ & 55.73 & 16.87 & 2.23 & 13.80 & 2.21 & 0.372 & 2.22 \\
\hline $\mathbf{Y}_{2} \times \mathbf{H}_{3}$ & 56.72 & 17.42 & 2.25 & 13.88 & 2.22 & 0.379 & 2.25 \\
\hline $\mathbf{Y}_{3} \times \mathbf{H}_{1}$ & 55.37 & 17.34 & 2.23 & 13.61 & 2.18 & 0.372 & 2.24 \\
\hline $\mathbf{Y}_{3} \times \mathbf{H}_{2}$ & 57.02 & 17.68 & 2.26 & 13.97 & 2.24 & 0.381 & 2.26 \\
\hline $\mathbf{Y}_{3} \times \mathbf{H}_{3}$ & 58.32 & 18.00 & 2.30 & 15.06 & 2.41 & 0.385 & 2.27 \\
\hline $\mathbf{Y}_{4} \times \mathbf{H}_{1}$ & 56.53 & 17.75 & 2.29 & 14.40 & 2.30 & 0.379 & 2.26 \\
\hline $\mathbf{Y}_{4} \times \mathbf{H}_{2}$ & 58.50 & 18.22 & 2.31 & 14.72 & 2.36 & 0.392 & 2.28 \\
\hline $\mathbf{Y}_{4} \times \mathbf{H}_{3}$ & 59.03 & 18.41 & 2.34 & 14.98 & 2.40 & 0.413 & 2.32 \\
\hline $\mathbf{Y}_{5} \times \mathbf{H}_{1}$ & 57.80 & 18.25 & 2.32 & 14.76 & 2.36 & 0.399 & 2.29 \\
\hline $\mathbf{Y}_{5} \times \mathbf{H}_{2}$ & 59.10 & 18.70 & 2.34 & 15.68 & 2.51 & 0.434 & 2.33 \\
\hline $\mathbf{Y}_{5} \times \mathbf{H}_{3}$ & 59.85 & 18.93 & 2.36 & 16.96 & 2.71 & 0.442 & 2.35 \\
\hline $\mathbf{L S D}_{0.05}$ & 0.51 & 0.08 & NS & 0.27 & 0.03 & 0.0003 & 0.0003 \\
\hline
\end{tabular}

increased the contents of amino acids, vitamins and cryoprotective agents as previously mentioned (Shady, 1978; Barnett et al., 1990 and Mahmoud, 2001).

Humic acid application significantly increased fruit yield/plant and fruit dry weight/plant relative to untreated plants more so by the high rate. Turkmen et al., (2004) has been reported that humic acid influences on plant yield through its effect on respiration, photosynthesis as well as dry matter accumulation in plants. Highest fruit yield/plant and calices dry weight/plant recorded by treating plants with yeast at $8 \mathrm{~g} / \mathrm{l}$ and humic acid at $2 \mathrm{~g} / \mathrm{l}$ relative to untreated plants. Vegetative and flowering growth stages and consequently yield components were enhanced by foliar application of yeast extract in many crops as reported (Fathy et al., 2000; Abou-Aly, 2005 and Wanas, 2006). 
Efficiency of yeast and humic acid foliar spray on Hibiscus sabdariffa $L$. biochemical analysis:

\section{Total chlorophyll and carbohydrates content:}

Chemical analysis of roselle leaves indicate that total chlorophyll and carbohydrates percentage in the leaves were significantly raised due to using any fertilization treatment in comparison to control plants more so when treated plants by the highest rate of yeast plus humic acid (Table 2). Yeast application induced the formation of photosynthetic pigments (Khama et al., 2013). Hassan (2007) and Stino et al., (2009) mentioned that yeast application increased total chlorophyll and carbohydrates content since it enhanced cell division and elongation producing more leaf area. Humic acid enhanced the quantitative and qualitative traits due to its positive role in raising respiration, photosynthesis rate and more accumulation of total chlorophyll and carbohydrate content in plants as found (Nardi et al,. 2002, Turkmen et al.,2004 and Cangi et al., 2006).

\section{Total anthocyanins percentage:}

Anthocyanins percentage significantly increased by using any level of yeast or humic acid relative to control plants (Table 2). Regarding the combination; the combination between any bio and organic fertilizers gave higher values compared to control plants but the differences were not significant. Parandian and Samavat (2012) reported that spraying humic acid at high concentration was efficient for increasing anthocyanins content in lilium petals. AbdelSalam (2016) illustrated that treated Ruby seedless grapevine by humic acid achieved an increment in total anthocyanins content.

\section{Total protein content:}

Results given in Table (2) illustrated that using any yeast treatment separately or combined with humic acid increased protein percentages in roselle leaves in comparison to untreated plants. High total proteins content in plant tissues were affected by humic acid application (Nardi et al., 2002).

\section{The macro elements ( $N, P$ and $K)$ :}

All used treatments maintained higher values of macro elements content in the leaves compared to the control plants as shown in Table (2). The highest values were obtained by the foliar spray of yeast at $8 \mathrm{~g} / \mathrm{l}$ and humic acid at $2 \mathrm{~g} / \mathrm{l}$. Macro and micro elements uptake in Asparagus shoots increased by using humic acid application (Cangi et al., 2006). The genes answerable for nitrogen and photosynthetic pathways were more activated by using humic acid (Jannin et al., 2012).

\section{REFERENCES}

Abdel-Salam, Maha M. (2016). Effect of foliar application with humic acid and two antioxidants on Ruby Seedless Grapevine. Middle East J. Agric. Res., 5(2):123-131.

Abou-Aly, H.A. (2005). Stimulatory effect of some yeast application on response of tomato plants to inoculation with biofertilizers. Annals. Agric. Sci. Moshtohor, 43(2):595-609.

Ahmed, Y.M.; Shalaby, E.A. and Shanan, N.T. (2011). The use of organic and inorganic cultures in improving vegetative growth, yield characters and antioxidant activity of roselle plants (Hibiscus sabdariffa L.)", Afri. J. Biotechnol., 10(11):1988-1996.

Albayrak, S. and Camas, N. (2005). Effects of different levels and application times of humic acid on root and leaf yield and yield components of forage turnip (Brassica rapa L.). J. Agron., 4(2):130133.

Alonso, M.L.; Kleiner, D. and Ortega, E. (2008). Spores of the mycorrhizal fungus Glomus mosseae host yeasts that solubilize phosphate and accumulate polyphosphates. Mycorrhiza, 18(4):197204. 
Aziz, Eman, E.; Gad, Nadia and Badran, Nadia, M. (2007). Effect of cobalt and nickel on plant growth, yield and flavonoids content of Hibiscus sabdariffa L. Aust. J. Basic Appl. Sci., 1(2):73-78.

Barnett, J.A.; Payne, R.W. and Yarrow, D. (1990). Yeasts Characteristics and Identification. Cambradge. Camb. CBZBR, 999 pp.

Boraste, A.; Vamsi, K.K.; Jhadav, A.; Khairnar, Y.; Gupta, N.; Trivedi, S.; Patil, P.; Gupta, G.; Gupta, M.; Mujapara, A.K. and Joshi, B. (2009). Biofertilizers: A novel tool for agriculture. Int. J. Microbiol. Res., $1(2): 23-31$.

Canellas, L.P. and Olivares, F.L. (2014). Physiological responses to humic substances as plant growth promoter. Chemical and Biological Technologies in Agriculture, 1(3):1-11.

Cangi, R.; Tarakcioglu, C. and Yasar, H. (2006). Effect of humic acid applications on yield, fruit characteristics and nutrient uptake in Ercis grape (Vitis vinifera L.) cultivar. Asian J. Chem., 18:1493-1499.

Chapman, H.D. and Pratt, P.F. (1961). Methods of Analysis for Soils, Plants and Waters. Univ. of Calif., Div. Agr. Sci., Berkeley, Calif. USA. 309 pp.

Cloete, K.; Valentine, A.; Stander, M.; Blomerus, L. and Botha, A. (2009). Evidence of symbiosis between the soil yeast Cryptococcus laurentii and a sclerophyllous medicinal shrub, Agathosma betulina (Berg.) Pillans. Microb. Ecol., 57(4):624-632.

Du, C.T. and Francis, F.J. (1973). Anthocyanins of roselle (Hibiscus sabdariffa L.). J. Food Sci., 38(5):810812.

El-Tarabily, K.A. (2004). Suppression of Rhizoctionia solani diseases of sugar beet by antagonistic and plant growthpromoting yeasts. Appl. Microbiol., 96: 69-75.
El-Tarabily, K.A. and Sivasithamparam, K. (2006). Potential of yeasts as biocontrol agents of soil-borne fungal plant pathogens and as plant growth promoters. MycoScience, 47(1):25-35.

Fathy, E.L.; Farid, S. and El-Desouky, S.A. (2000). Induce cold tolerance of outdoor tomato during early summer seasons by using adenosine tri phosphate (ATP), yeast, other natural and chemical treatments to improve their fruiting and yield. J. Agric. Sci. Mansura. Univ., 5(1):377-401.

Hassan, Hayat, A. (2007). Physiological Studies on Hibiscus sabdariffa L. Production in New Reclamated Soils. M.Sc. Thesis, Fac. Agric., Zagazig Univ. Egypt, 229 pp.

Hendawy, S.F.; Hussein, M.S.; El-Gohary, A.E. and Ibrahim, M.E. (2015). Effect of foliar organic fertilization on the growth, yield and oil content of Mentha piperita var. citrata. Asian J. of Agric. Res., 9(5):237-248.

Herbert, D.; Philips, P.J. and Strange, R.E. (1971). Chemical analysis of microbial cells. In: Methods in Microbiology. Norris, J.R. and D.W. Ribbons (Ed.). 5B: 209-344.

Hesham, A. and Mohamed, H.M. (2011). Molecular genetic identification of yeast strains isolated from Egyptian soils for solubilization of inorganic phosphates and growth promotion of corn plants. J. Microbiol. Biotechnol., 21(1):55-61.

Ismail, A.; Ikram, E.H.K. and Nazri, H.S.M. (2008). Roselle (Hibiscus sabdariffa L.) seeds - nutritional composition, protein quality and health benefits. Food, 2(1):116.

Jannin, L.; Arkoun, M.; Ourry, A.; Laîné, P.; Goux, D.; Garnica, M.; Fuente, S. M.; San, F.; Rancisco, S.; Baigorri, R.; Cruz, F.; Houdusse, F.; Garcia-Mina, J.M.; Yvin, J.C. and Etienne, P. (2012). Microarray analysis of humic acid effects on Brassica napus growth: Involvement 
of N, C and S metabolisms. Plant Soil, 359(1-2):297-319.

Khama, O.R.; Cedric, K. and Nelson, L.E. (2013). Effect of soil adjustment with yeasts as bio-fertilizers on the growth and yield of sugar beet. Int. J. Manures Fertilizers, 2(11):424-433.

Mahmoud, T.R. (2001). Botanical Studies on the Growth and Germination of Mahnolia (Magnolia grandiflora L.) Plants. M.Sc. Thesis. Fac. Agric. Moshtohor, Zagazig Univ. Egypt, 103 pp.

Mohamed, R.; Fernandez, J.; Pineda, M. and Aguilar, M. (2007). Roselle (Hibiscus sabdariffa) seed oil is a rich source of $\gamma_{-}$ Tocopherol. J. Food Sci., 72(2):207-211.

Mok, D.W.S. and Mok, M.C. (2001). Cytokinin metabolism and action. Ann. Rev. Plant Physiol. Plant Mol. Biol., 52: 89-118.

Nardi, S.; Pizzeghello, D.; Muscolo, A. and Vianello, A. (2002). Physiological effects of humic substances on higher plants. Soil Biol. and Biochem., 34(11):15271536.

Nassar. A.H.; El-Tarabily, Kh. A. and Sivasithamparam, K. (2005). Promotion of plant growth by an auxin-producing isolate of the yeast Williopsis saturnus endophytic in maize (Zea mays L.) roots. Biol. Fertil. Soils, 42(2):97-108.

Oliver R.K. ; Kaiser, C. and Lule, E.N. (2013). Effect of soil adjustment with yeasts as bio-fertilizers on the growth and yield of sugar beet. Int. J. Manures Fertilizers. 2(11):424-433.

Omran, Y.A.M.M. (2000). Studies on Histophysiological Effect of Hydrogen Cyanamide (Dormex) and Yeast Application on Bud Fertility, Vegetative Growth and Yield of "Roumi Red" Grape Cultivar. Ph.D. Thesis, Fac. of Agric., Assiut Univ., Egypt, 220 pp.

Parandian, F. and Samavat, S. (2012). Effects of fulvic and humic acid on anthocyanin, soluble sugar, $\propto$-amylase enzyme and some micronutrient elements in lilium. Intl. Res. J. Appl. Basic. Sci., 3(5):924-929.

Pirie, N.W. (1955). Protein. In: Modern Methods of Plant Analysis, Peach, K. and M.V. Traacey (Eds.). Vol. 4. Springer Verlag, Berlin, Germany, p: 23-68.

Rao, P.U. (1996). Nutrient composition and biological evaluation of mesta (Hibiscus sabdariffa) seeds. Plant Foods Hum. Nutr., 49(1):27-34.

Russo, R.O. and Berlyn, G.P. (1990). The use of organic biostimulants to help low input sustainable agriculture. J. of Sustainable Agric., 1(2):19-42.

Shady, M.A. (1978). The yeasts. Adv. Cour. For Post Grad St. In Microbial., Agric. Botany Dept., Fac. of Agric., Mansura Univ., p: 146-247.

Sharaf, A. (1962). The pharmacological characteristics of Hibiscus sabdariffa L. Planta Med., 10:48-52.

Stino, R.G.; Mohsen, A.T.; Maksoud, M.A.; Abd El-Migeed, M.M.M.; Gomaa, A.M. and Ibrahim, A.Y. (2009). Bio-organic fertilization and its impact on Apricot young trees in newly reclaimed soil. American- Eurasion. J. Agric. Environ. Sci., 6(1):62-69.

Turkmen, O.; Dursun, A.; Turan, M. and Erdinc, C. (2004). Calcium and humic acid affect seed germination, growth, and nutrient content of tomato (Lycopersicon esculentum L.) seedlings under saline soil conditions. Acta Agriculturae Scandinavica, Section B - Soil and Plant Sci., 54(3):168-174.

Waller, R.A. and Duncan, D.B. (1969). A bayes rule for the symmetric multiple comparisons problem. J. Am. Stat. Assoc., 64:1484-1503.

Wanas, A.L. (2006). Trails for improving growth and productivity of tomato plants grown in winter. Annals. Agric. Sci. Moshtohor, 44(3):466-471. 


\title{
تأثير الخميرة وحمض الهيوميك على نمو وإنتاجية نبات الكركدية
}

\author{
رشا سليم الصيرفى ماعلى \\ قسم البساتين، كلية الزر اعة، جامعة طنطا، طنطا، مصر .
}

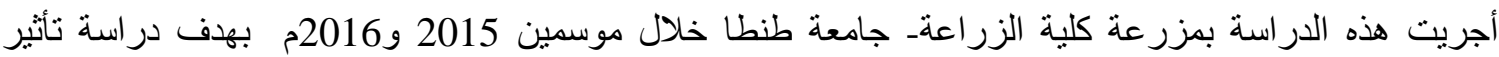

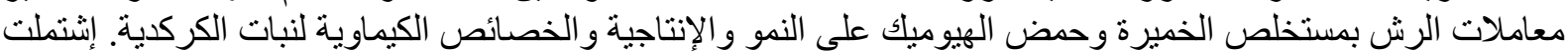

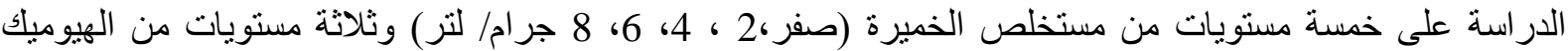

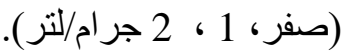

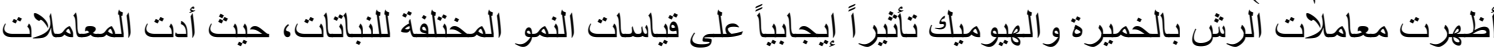

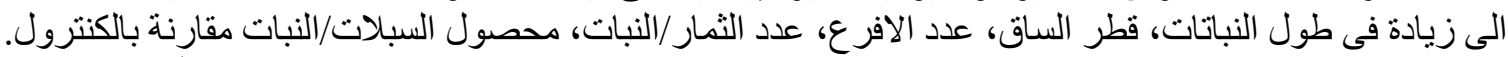

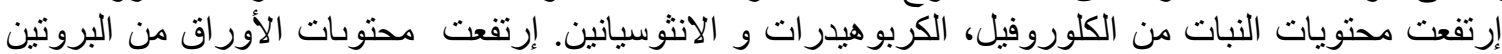

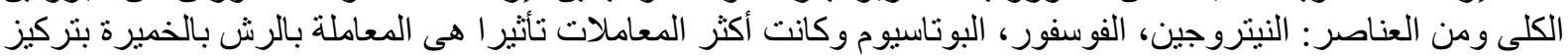

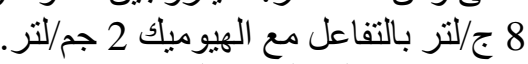

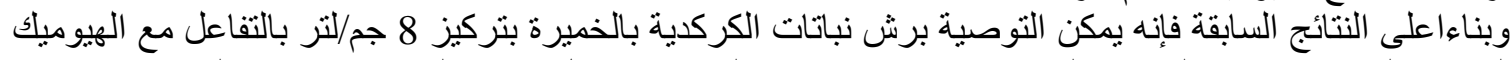

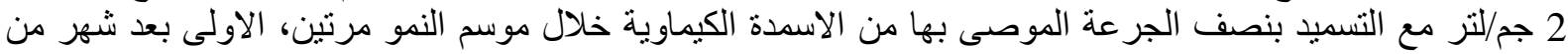
الزر اعة والثانية بعد الرشة الاولى بشهر لتحسين النمو الخضرى و المحصولى وكذلك المركبات الكيماوية لنبات الكركدية. 